\title{
CARTOGRAFIA VIRAL E HASHTAGS: COMO UM \#MAPA PODE GANHAR ENGAJAMENTO NAS REDES SOCIAIS?
}

\author{
Carina Petsch ${ }^{1}$ \\ Natália Lampert Batista² \\ Ana Paula Kiefer ${ }^{3}$ \\ Carla Pizzuti Savian ${ }^{4}$ \\ Franciele Delevati Ben ${ }^{5}$ \\ Francisco Augusto Altermann 6 \\ Gustavo Soares Arrial ${ }^{7}$
}

\begin{abstract}
Resumo: Os objetivos deste artigo são (i) avaliar o engajamento da página Cartografia Viral no Instagram após o início do uso de hashtags; (ii) avaliar o engajamento social das postagens de acordo com 15 hashtags; e (iii) analisar as publicações de destaque destas 15 hashtags. Foram utilizados dados obtidos em comentários, curtidas e métricas disponíveis na mídia social Instagram. Os resultados indicam que o uso das hashtags representaram um aumento no número de contas alcançadas, impressões e seguidores. A posição de destaque das hashtags são marcadas por dois processos opostos: efemeridade das postagens e a cristalização de conteúdos de páginas com grande número de seguidores. Quanto ao conteúdo dos mapas, verificamos que três deles apresentaram erros espaciais e de dados, além da ausência de elementos fundamentais. Portanto, o estudo abre caminhos para novas discussões e coloca em voga um tema ainda pouco debatido na Cartografia acadêmica.
\end{abstract}

Palavras-chave: Cartografia Viral, Mapas virais, Viralização de conteúdo.

\section{VIRAL CARTOGRAPHY AND HASHTAGS: HOW CAN A \#MAP WIN ENGAGEMENT IN SOCIAL NETWORKS?}

Absctract: This paper aims to (i) to evaluate the engagement of the Viral Cartography page on Instagram after the use of hashtags began; (ii) evaluate the social engagement of the posts according to 15 hashtags; and (iii) analyze the prominent publications of these 15 hashtags. Data obtained from comments, likes and metrics available on the social media Instagram were used. The results indicate that the use of hashtags represented an increase in the number of accounts reached, impressions

\footnotetext{
${ }^{1}$ Professora Adjunta da Universidade Federal de Santa Maria (UFSM). Email: carinapetsch@gmail.com

${ }^{2}$ Professora Adjunta da Universidade Federal de Santa Maria (UFSM). Email: natilbatista3@ gmail.com

${ }^{3}$ Graduanda do curso de geografia na Universidade Federal de Santa Maria (UFSM). Email: anapaulakiefer@ gmail.com

${ }^{4}$ Graduanda do curso de geografia na Universidade Federal de Santa Maria (UFSM). Email: carlapizzutisavian@hotmail.com

${ }^{5}$ Graduanda do curso de geografia na Universidade Federal de Santa Maria (UFSM). Email: francielidelevattiben@gmail.com

${ }^{6}$ Graduando do curso de geografia na Universidade Federal de Santa Maria (UFSM). Email: franciscoaltermann9240@gmail.com

${ }^{7}$ Graduando do curso de geografia na Universidade Federal de Santa Maria (UFSM). Email: gustavo.arrial@ hotmail.com
} 
and followers. The prominent position of hashtags is marked by two opposing processes: ephemerality of posts and the crystallization of page content with a large number of followers. As for the content of the maps, we found that three of them showed spatial and data errors, in addition to the absence of fundamental elements. Therefore, the study opens a way to new discussions and brings into focus a topic that has not been much debated in academic cartography.

Keywords: Viral Cartography, Viral maps, Viralization of content.

\section{INTRODUÇÃO}

É necessário reconhecer que as mídias sociais são parte do cotidiano de milhares de indivíduos. "As novas tecnologias permitiram a criação de meios de comunicação mais interativos, liberando os indivíduos das limitações de espaço e tempo, tornando a comunicação mais flexível" (VERMELHO et al, 2014, p. 182)". Fazem parte das mídias sociais, a troca de informações, acesso a notícias, conversas entre indivíduos fisicamente distantes, o cancelamento de pessoas em função de algum posicionamento e a viralização de conteúdo. Nesse contexto, os conteúdos virais constituem informações compartilhadas de forma rápida e com alcance local, regional ou global similar à propagação de uma doença infecciosa (GOEL et al., 2015). Mas, então, qual a associação entre Geografia, Cartografia e conteúdos virais?

O trabalho de Robinson (2019) traz os termos "Viral Cartography" e "viral map" pela primeira vez. O autor analisou mapas de locais onde seria possível visualizar um eclipse e uma série de mapas relacionados à eleição presidencial de 2016, nos Estados Unidos da América (EUA). Mais recentemente, Shannon e Walker (2020) apresentaram outra contribuição para a Cartografia Viral, visto que o objetivo da pesquisa se voltou para a criação de mapas virais, apontando quais fatores internos e externos aos próprios mapas contribuíram para sua popularização nas plataformas de mídias sociais. Sendo assim, os mapas também fazem parte deste universo de conteúdos com potencial viral, ou seja, de atingir diversas contas nas mídias sociais, sobretudo na pandemia da COVID-19 com os mapas espacializando casos e óbitos causados pelo vírus SARS-CoV-2. Dessa forma, ressaltamos que a potencialidade de um mapa viralizar se relaciona diretamente com a sua capacidade de surpreender, causar emoções (boas ou assustadoras) e de gerar engajamento por ser um assunto em voga.

Os mapas virais, até agora, receberam pouca atenção na Cartografia acadêmica (ROBINSON, 2019), o que demanda de nós pesquisadores um novo olhar sobre as mídias sociais, em ascensão e com capacidade de influenciar significativamente os rumos da sociedade, e uma análise de quanto a sociedade e nossos alunos recebem informações espaciais através do Facebook, Instagram, Twitter, entre outras redes. Contudo, Robinson (2019) também se preocupa em como identificar um mapa viral, ou seja, suas repostagens dentro da plataforma de mídia social. Nesse sentido, nossa pesquisa apresenta uma contribuição para a preocupação exposta pelo autor, onde ao nosso ver o uso das hashtags podem representar uma forma de otimizar a pesquisa e a análise de mapas virais, visto que o próprio algoritmo do Instagram fornece postagens de destaque - mapas que estão tendo engajamento social.

Rauschnabel (2019) ressalta que poucos estudos se preocuparam em utilizar as hashtags como um meio de buscar conteúdos nas plataformas de mídia social. "O conceito de hashtags é semelhante a tags usadas em serviços de compartilhamento 
de fotos e vídeos (...) um conjunto de hashtags se relaciona a um evento específico" (MURZINTCEV; CHENG, 2017, p.2). Ou seja, a partir da busca por determinada tag podemos ter acesso aos principais conteúdos postados, visto que o uso da \# transforma a palavra em hiperlink e se associa ao mecanismo de busca da rede social. Segundo Omega (2020) o uso de hashtags faz parte da nossa vida digital, visto que existe uma hashtag para quase todos os interesses sociais. Sinpeng (2021) complementa que as hashtags:

(...) vinculam palavras ou frases específicas, tornando o conteúdo online facilmente pesquisável e compartilhável em massa. Hashtags não são apenas marcadores de importância para questões ou eventos específicos; eles também servem como ferramentas de definição de agenda e quadros discursivos que podem ser usados para criar identidades coletivas compartilhadas (SINPENG, 2021, p. 4).

Rauschnabel (2019) e Omega (2020) relatam que as hashtags vão muito além de reunir conteúdo nas redes sociais, representam um elemento pertencente à comunicação contemporânea por meio das mídias sociais. Carmean e Morris (2015) ao realizarem uma pesquisa sobre as tags de um conjunto de 2700 fotos, identificaram que aproximadamente $10 \%$ dessas fotos estavam relacionadas com palavras de emoção; Ye at al (2017) relatam que comparando os usuários do sexo masculino, as do sexo feminino tendem a usar descrições emocionais e de hashtag positivas (YE et al, 2017); e Ferrara et al. (2014) ao estudarem o comportamento do usuário enquanto selecionam hashtags para suas fotografias, também salientam que ocorre o uso delas para salientar alguma característica pessoal. Sendo assim, as hashtags ainda podem demonstrar interações e interpretações espaciais dos mapas, além da sua postagem efetivamente.

Hashtags não são totalmente novas na web, de acordo com Giannoulakis e Tsapatsoulis (2016). Os usuários começaram a usá-los com o Internet Relay Chat (IRC) para categorizar os itens em grupos e Chris Messina foi o primeiro a usar hashtags, nas mídias sociais contemporâneas (GIANNOULAKIS; TSAPATSOULIS, 2016). Ademais, o uso de hashtags em artigos científicos já foi documentada. Sinpeng et al (2021) avaliaram o uso de hashtags por ativistas durante os protestos antigovernamentais de 2020, na Tailândia. Murzintcev e Cheng (2017) elaboraram um método automatizado para identificação de postagens relacionadas a um evento específico, através de hashtags.

Dessa forma, os objetivos deste artigo são (i) avaliar o engajamento da página Cartografia Viral no Instagram após o início do uso de hashtags; (ii) avaliar o engajamento social das postagens da Cartografia Viral de acordo com 15 hashtags pré-selecionadas; e (iii) analisar as publicações de destaque das 15 hashtags utilizadas no que se refere a presença de mapas, suas temáticas, número de curtidas e principais comentários.

\section{MATERIAIS E MÉTODOS}

A pesquisa em questão possui um caráter quali-quantitativo e foi desenvolvida a partir de dados obtidos em comentários, curtidas e métricas de engajamento social fornecidas pela mídia social Instagram. 


\section{POSTAGEM DE MAPAS UTILIZANDO HASHTAGS E AVALIAÇÃO DO ENGAJAMENTO NA PÁGINA CARTOGRAFIA VIRAL}

Visando cumprir o primeiro objetivo desta pesquisa, no período de 01 de novembro de 2020 a 31 de janeiro de 2021, todas as postagens da página Cartografia Viral passaram a ser publicadas sempre com as mesmas hashtags (Quadro 1), visando atrair mais público para o perfil e aumentar a divulgação do conteúdo científico. As postagens eram realizadas sempre na segunda, terça e quinta feira, dias de maior acesso ao perfil, segundo estatística do perfil no Instagram. Os temas postados serão apresentados no item 4.2. Em sequência, foi realizada uma avaliação do engajamento social (ROBINSON 2019) na página Cartografia Viral, a partir da análise semanal dos seguintes dados:

- Número de seguidores;

- Contas alcançadas;

- Interação com o conteúdo;

- Impressões e;

- Visitas ao perfil.

Todas as métricas citadas são fornecidas na ferramenta Insights do Instagram e os dados foram compilados e organizados no software Excel, onde também foram elaborados gráficos. As hashtags escolhidas foram diversas (Quadro 1), como por exemplo, memes, curiosidades, geografia, mapas, cartografia, entre outras, e contemplando diferentes números de postagens (entre 958 e 1.072.913).

A análise do desempenho das postagens da página Cartografia Viral, segundo objetivo da pesquisa, em cada uma das hashtags foi realizada 24 horas após a publicação do conteúdo, na seção de "destaques" e de "recentes". Ressalta-se que além das hashtags mencionadas no Quadro 1, também utilizamos algumas específicas ao tema postado, que serão debatidas posteriormente.

Quadro 1. Hashtags utilizadas nas postagens da página Cartografia Viral e número de postagens apresentadas por elas em 31 de março de 2021.

\begin{tabular}{|c|c|c|c|}
\hline Hashtags & $\begin{array}{c}\text { Número de } \\
\text { postagens }\end{array}$ & Hashtags & $\begin{array}{c}\text { Número de } \\
\text { postagens }\end{array}$ \\
\hline geografianews/ & 4979 & geografiafisica/ & 6023 \\
\hline geocuriosidades/ & 333 & geografiadobrasil/ & 7295 \\
\hline geografiageral/ & 16111 & geopocket/ & 1572 \\
\hline geografiasemlimites/ & 5203 & geografiasemdivisas/ & 958 \\
\hline geografia/ & 592953 & geografía/ & 48040 \\
\hline geografiasemfronteiras/ & 4809 & cartografias/ & 2692 \\
\hline geo/ & 1072913 & mapas/ & 114619 \\
\hline geografiaenem/ & 8057 & cartografia/ & 71878 \\
\hline
\end{tabular}

Fonte: Elaborado pelos autores, 2021

\footnotetext{
${ }^{8}$ Cada uma das hashtags do Instagram fornecem um quadro de postagens mais recentes (ordem temporal de postagem) e outro quadro com as postagens de destaque, ou seja, aquelas que apresentaram maior engajamento entre os seguidores.
} 
Buscando identificar quais eram os conteúdos da seção de destaque das hashtags utilizadas, terceiro objetivo da pesquisa, realizamos uma análise no período de um mês (março de 2021), onde uma vez por semana foi feita a avaliação das 9 postagens de destaque de cada hashtag. Foram levantados dados de:

- $\quad$ Conteúdo da postagem;

- Média de curtidas de postagens com mapas e sem mapas;

- Média de comentários com postagens com mapas e sem mapas;

- Comentários, somente nas publicações com mapas; e

- A dinâmica semanal (quais as postagens que permaneceram em destaque no período avaliado), denominada por nós de viralidade temporal dos mapas, apresentada na forma de planilha cromática.

Destaca-se que os dados de curtidas e comentários foram obtidos diretamente nas postagens e compilados no software Excel. Os temas das postagens com mapas foram analisados fazendo uma nuvem de palavras no aplicativo Mentimeter ${ }^{9}$. Salientase que conforme os temas apareceram por mais de uma semana na seção de destaque, ou se repetiam em mais de uma hashtag, foram representados com um tamanho proporcional maior na figura gerada pelo aplicativo.

\section{RESULTADOS E DISCUSSÕES}

O projeto de extensão da Universidade Federal de Santa Maria (UFSM), denominado Cartografia Viral teve início em abril de 2020, com o propósito de divulgar conteúdos geográficos nas redes sociais Facebook e Instagram, assim como compreender quais assuntos possuem maior potencial de engajamento social (ROBINSON, 2019). Conta atualmente com a participação de duas docentes e quatro discentes do curso de graduação em Geografia. Durante sete meses (abril-outubro de 2020), o conteúdo postado foi diverso e não obedeceu a um layout (padrão de cores, tipo e tamanho de letras) igual para todas as postagens. O que ao nosso ver, foi um período de testagem para compreender os aspectos de engajamento social do Instagram e para a própria organização do grupo.

A partir de novembro de 2020, o projeto Cartografia Viral passou a postar somente mapas com todas as convenções cartográficas, seguindo um único layout, nas cores amarelo e azul escuro. Toda parte descritiva passou a ser inserida na legenda da imagem, visando buscar uma identidade visual para a página. Essa alteração foi definida em função do que foi exposto por outros autores da temática de Cartografia Viral, como Muehlenhaus (2014), que debate sobre estilos de mapa persuasivos - que ao nosso ver é um termo que se assemelha à "virais" - e como se destacam nos mecanismos de busca rápida de informações. Robinson (2019, p. 297) que também relata que "o layout, a hierarquia visual e o design tipográfico em um mapa viral também podem ser fatores importantes a serem considerados" para que ele viralize nas redes sociais.

\footnotetext{
${ }^{9}$ Disponível em https://www.mentimeter.com/.
} 


\section{ANÁLISE DO ENGAJAMENTO DO PERFIL CARTOGRAFIA VIRAL: AS HASHTAGS ATRAIIRAM UM MAIOR PÚBLICO?}

No período de análise, tivemos um ganho de 180 seguidores, sendo que 92 foram registrados no primeiro mês de avaliação. Consideramos que isso ocorreu em função da adoção de hashtags nas postagens, sendo que através destas um número maior de contas foi alcançado, proporcionando 0 crescimento de seguidores. Ressaltamos que apesar de não ser objeto de discussão deste artigo, o ganho de seguidores foi maior no início do projeto (abril e maio de 2020 onde somamos 1000 seguidores) estabilizando-se com o passar dos meses. $O$ uso de hashtags proporcionou novamente o crescimento de seguidores para a página.

Quanto a métrica de número de contas alcançadas (Figura 1), evidencia-se que o conteúdo postado interferiu neste índice. Destacamos que na semana após a aplicação do Exame Nacional do Ensino Médio (ENEM), 20 a 27 de janeiro de 2021, quando postamos dois mapas analisando questões de prova, tivemos 1646 contas alcançadas para o primeiro e 809 para o segundo mapa. Podemos associar isso ao que denominamos de viralidade temporal dos mapas, ou seja, no dia imediatamente posterior ao ENEM, o assunto é mais procurado e tem maior alcance de contas. Em contrapartida, 48 horas depois, o interesse dos usuários pelo conteúdo cai, diminuindo as buscas sobre o assunto. Shannon e Walker (2020, p. 67) destacam ainda que os mapas virais "têm laços profundos com o senso de identidade social dos indivíduos e com contextos espaço-temporais específicos", como é o caso do ENEM.

Na semana entre 16 e 23 de novembro de 2020, tivemos um somatório de 7723 contas alcançadas; sendo que uma postagem sobre o gelo em movimento na Antártica teve 1091 contas alcançadas e 568 impressões - número de acessos a partir das hashtags. Robinson (2019) destaca que é fundamental estabelecer um públicoalvo que recebe, lê e interpreta as informações do mapa viral. Neste caso, a postagem com um mapa da prova do ENEM se remeteu ao público de estudantes que realizaram o exame; enquanto o mapa da Antártica buscou um público interessado em curiosidades.

Quanto à métrica de interação com o conteúdo, consideramos que não foi muito adequada quando analisada em um somatório semanal, porque observou-se que a variação entre as postagens foi grande, entre 33 e 100.

A métrica de impressões diz respeito à quantidade de vezes que uma postagem foi visualizada, independente se foi pela mesma conta ou não. Destaca-se novamente a semana de 16 a 23 novembro de 2020 (Figura 1), onde a postagem sobre o gelo em movimento atingiu 1207 impressões e 568 foram de hashtags; e outra sobre a mineração no estado de Goiás, com 1176 impressões, sendo 321 de hashtags. A semana de 12 a 19 de janeiro se destacou pelas publicações da "Cartografia de Al Idrisi" com 887 impressões e 342 eram de hashtags e "casos de COVID-19 no RS", com 929 impressões e 323 foram de hashtags.

A publicação com maior número de impressões, em todo o período, foi sobre a Geocronologia do Atlântico, com 1316 impressões, sendo 762 de hashtags. Os assuntos se destacam por serem diferentes daqueles comumente observados nas mídias sociais, aguçando a curiosidade dos usuários, ou muito debatidos como o caso da COVID-19, ou ainda sobre locais específicos, no caso a mineração em Goiás. Labadessa (2012, p.87) destaca que "muitos 'amigos' se tornam amigos de outros por pura curiosidade em saber mais sobre a vida pessoal de quem o adicionou" e Thomas e Vinuales (2017) apontam que a curiosidade também influencia nas postagens sobre produtos para consumidores. Nós destacamos que o mesmo ocorre na viralização dos 
mapas, a curiosidade é um fator crucial para atrair o interesse dos seguidores por estes conteúdos, assim, quanto mais instigante, associado a curiosidades em alta e/ou diferente, mais chances o conteúdo tem de se tornar viral.

A semana de 16 a 23 de novembro de 2020 se destacou também por possuir a postagem com maior número de visitas à página, no período avaliado. A postagem foi sobre o Índice de Gini conseguiu 22 visitas ao perfil. Destaca-se que as hashtags foram responsáveis por somente 3 impressões nesta postagem, então acredita-se que o conteúdo tenha sido atraente para o próprio público da página, na sua maioria, da Geografia.

Figura 1. Análise de engajamento social de acordo com as métricas do Instagram.

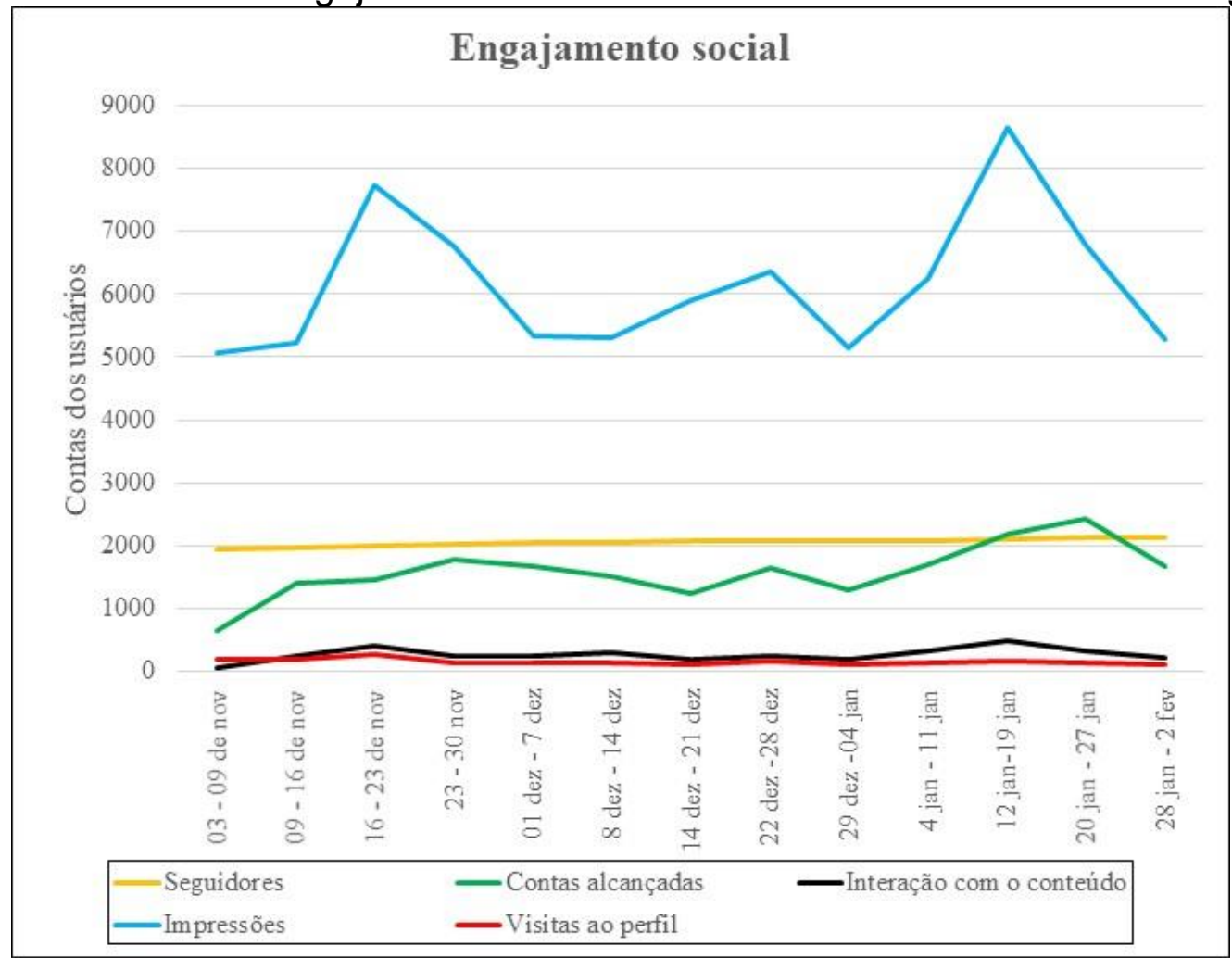

Fonte: Elaborado pelos autores, 2021

\section{ANÁLISE DAS POSTAGENS DA CARTOGRAFIA VIRAL EM RELACEÃO AS SEÇÕES DE DESTAQUE E RECENTES DAS HASHTAGS: CONSEGGUIMOS VIRALIZAR NOSSOS MAPAS?}

Destacamos que apesar de haver algumas variações na posição em que as postagens da Cartografia Viral ocupavam na seção de "mais recentes" da hashtag (Figura 2), após 24 horas em \#mapas, \#cartografia, \#geo e \#geografia (hashtags com mais de 71878 publicações) as publicações já estavam abaixo das 50 mais recentes. Sendo assim, em hashtags com postagens de páginas com grande número de seguidores, os mapas são bastante efêmeros, perdendo rapidamente engajamento social, em meio a tantas outras postagens. Em hashtags com menos postagens, como \#geocuriosidades (333 postagens), as publicações da Cartografia Viral permaneciam entre a primeira e terceira postagem mais recente. Nas \#geografía e \#geografiageral algumas publicações estavam abaixo das mais recentes, após 24 horas, embora a maioria se encontre na posição 37 . Nenhuma publicação ocupou a posição de destaque das hashtags. 
Figura 2. Posição ocupada pelas postagens da Cartografia Viral, após 24 horas, em cada uma das hashtags ${ }^{10}$.

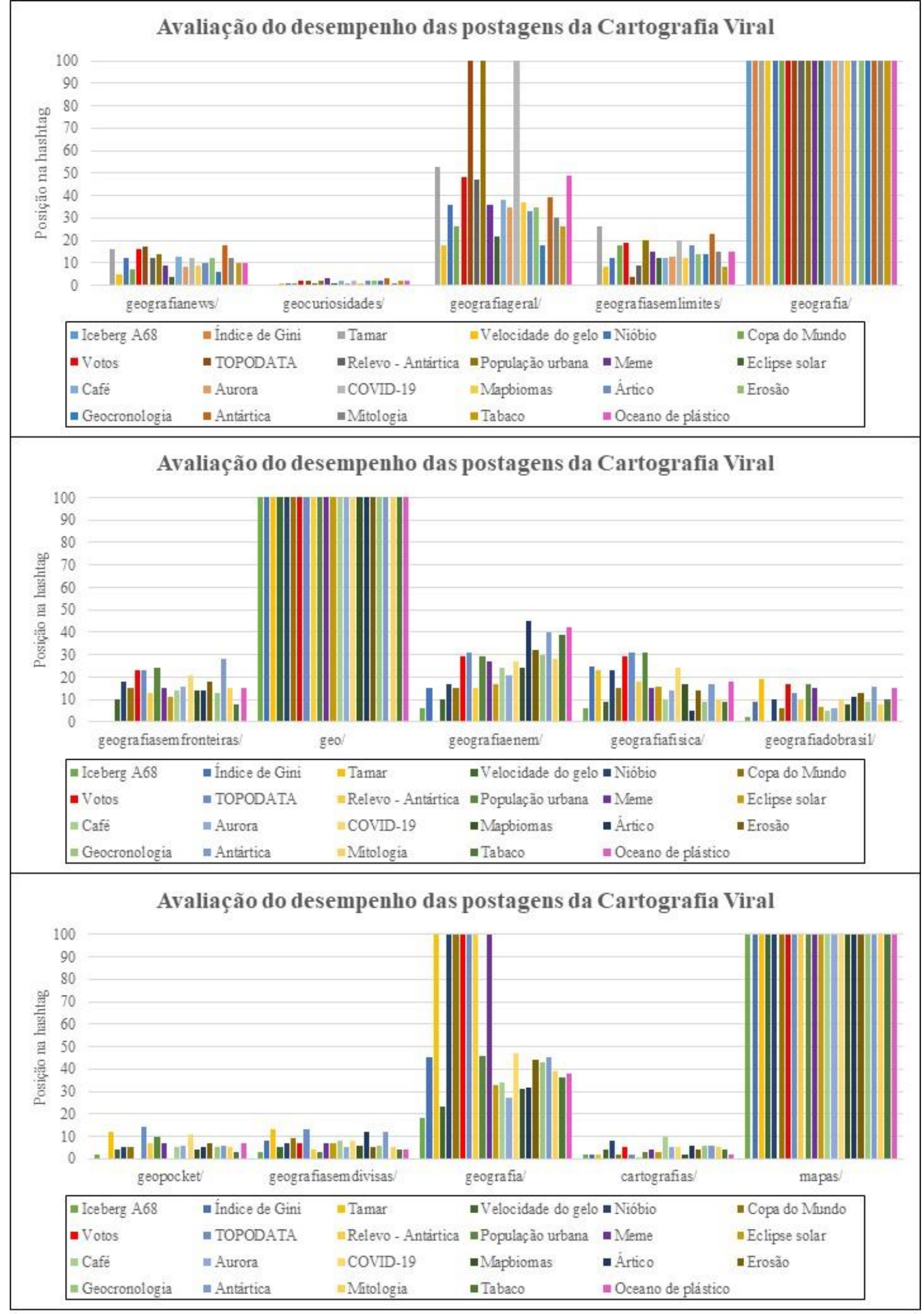

Fonte: Elaborado pelos autores, 2021

${ }^{10}$ Para padronizar os dados, foi assumido que para todas as publicações acima das 50 mais recentes, foi atribuído o valor de 100. 
Robinson (2019, p. 295) destaca que "ainda não sabemos até que ponto mapas virais têm um impacto além de sua aparente efemeridade". De fato, os mapas postados rapidamente desaparecem das publicações mais recentes. Em menos de 24 horas, vários novos conteúdos são postados! Essa efemeridade das postagens e do interesse das pessoas nos temas publicados pode estar associada às características da modernidade líquida, que conforme Bauman (2001), é marcada pela busca de prazeres imediatos e de interesses fluidos. Assim como um tema pode estar em voga, ele rapidamente é substituído e o engajamento das hashtags flui para outros focos de atenção.

Salienta-se que avaliar o potencial de engajamento social que as postagens da Cartografia Viral possuem, em ocuparem as principais publicações de determinada hashtag, fornece indícios sobre quais são os assuntos preferidos dos nossos seguidores, e consequentemente o que tem maior potencial de viralizar ou como fazer um tema acadêmico/científico viralizar. Shannon e Walker (2020) também buscaram criar postagens e avaliar seu potencial de engajamento social, porém não com hashtags. Destaca-se assim que é um campo de pesquisas aberto, com poucas respostas.

Isto posto, destacamos que além das hashtags fixas (Quadro 1) utilizamos 84 hashtags específicas nas postagens dos três meses analisados, que possuíam uma variação entre 6 e 4.785 .547 postagens (Figura 3). Destacamos que somente em uma publicação da Cartografia Viral, sobre a votação feminina, tivemos com a \#geofeminista (16 publicações) o segundo lugar das mais relevantes e na publicação sobre MapBiomas Brasil em \#mapbioma (6 publicações) ficamos em terceiro lugar das mais relevantes. Foram as hashtags com o menor número de postagens.

$\mathrm{O}$ uso de hashtags específicas é fundamental para a tentativa de direcionar a postagem para um público particular e que possa ter maior interesse. Aqui nos deparamos com uma situação na qual nós não conhecemos quais são os gostos, passatempos, quais são as histórias de nossos seguidores, então o uso das hashtags mais específicas pode contribuir no sentido de atingir e "criar identidades coletivas compartilhadas" (SINPENG, 2021, p.4), ou seja, fazendo repetidas tentativas de uso de uma hashtag podemos atingir alguns grupos que irão consumir tal conteúdo. Ademais, também sugerimos para trabalhos futuros o uso de hashtags que se remetem a localizações, buscando identidades topofílicas. Conforme Robinson (2019, p.296) expõe "na cartografia viral, as referências de localização também podem estar implícitas", no caso nas hashtags. Shannon e Walker (2020, p.74) também relataram que ao produzirem mapas virais "as reações afetivas estavam ligadas a identidades regionais e sociais dos usuários".

Embora saibamos que os seguidores do perfil da Cartografia Viral são, na sua maioria, da Geografia, em função de termos muitos conhecidos como nossos seguidores, o uso de hashtags que fazem menção somente a Geografia acabam limitando nosso potencial de atingir outros grupos específicos. Além disso, por não contarmos com um número de seguidores tão expressivos como outras contas ou ainda não dedicamos muitas horas para gerar engajamento curtindo, comentando e compartilhando conteúdos de outras páginas, acabamos ficando mais limitados ao público que já conhece a página e pessoas que pesquisam por temas que usamos nas hashtags. Nesse sentido, quando fazemos algumas publicações consideradas interdisciplinares buscamos envolver hashtags que façam menção a outras áreas do conhecimento, fomentando um debate mais amplo dos conteúdos e criando condições de interação da educação geográfica com outras ciências, no âmbito do ciberespaço. Por exemplo, em alguns temas transversais como aqueles ligados ao meio ambiente 
(e.g postagem sobre o projeto Tamar) ou sociologia e história (e.g. votação em mulheres), é necessário diversificar o uso das hashtags. Por vezes, algo que nas hashtags geográficas não desperte interesse do público, pode abrir novos horizontes para seguidores de outras áreas.

Figura 3.Número de postagens das hashtags específicas utilizadas.

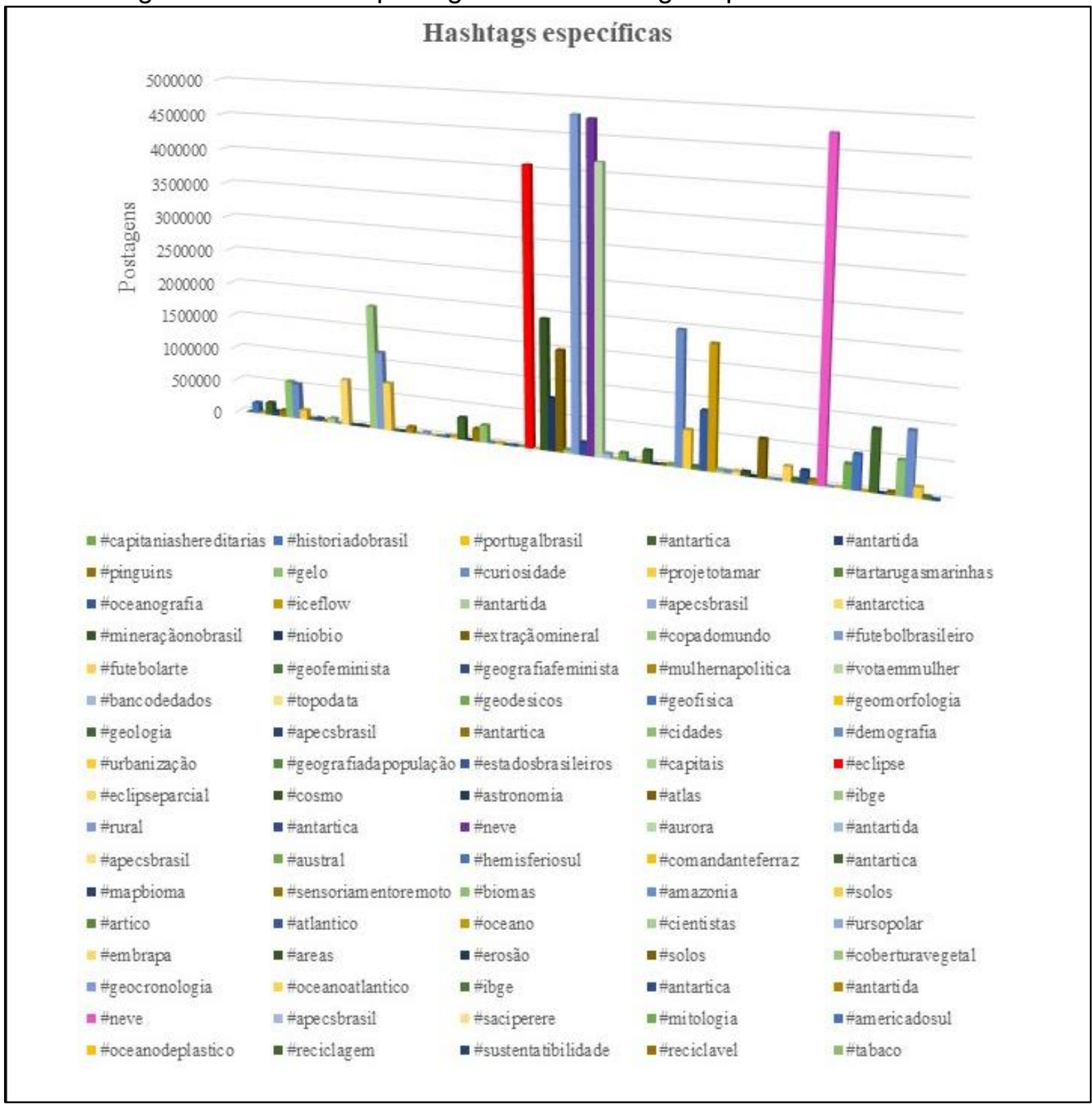

Fonte: Elaborado pelos autores, 2021

Infelizmente, o uso de hashtags específicas também não representou a ocupação de uma vaga no grupo das publicações de destaque das hashtags. Diante do fato de que somente duas publicações conseguiram atingir o engajamento necessário para ocupar as principais publicações das hashtags utilizadas, a próxima etapa de nossa investigação foi buscar responder a seguinte indagação: "quais são as postagens que ocupam essa classe dos mais relevantes?". Destacamos que isso envolve também mecanismos complexos do algoritmo desta mídia social, ou seja, o conteúdo que é mostrado para determinado usuário está ligado ao que ele comumente costuma curtir e compartilhar, bem como com o tempo que os usuários interagem 
dentro da rede social, interferindo nessa posição de destaque das hashtags. Ademais, as hashtags utilizadas e o conteúdo dos mapas podem não estimular questões de identidade, emoções e sentimentos (RAUSCHNABEL, 2019; OMEGA, 2020) dos seguidores em relação ao mapas postados pelo perfil Cartografia Viral.

\section{ANÁLISE DAS PUBLICAÇÕES DE DESTAQUE DAS HASHTAGS UTILIZADAS: NO QUE OS SEGUIDORES "DÃO LIKE"?}

Analisando as postagens de destaque das 15 hashtags avaliadas, verificamos que durante o mês de março de 2021, os mapas foram a minoria em 13 hashtags (Quadro 2). Somente em \#geografiadobrasil e \#geopocket os mapas ocupam a maioria das postagens de destaque. Para a \#geopocket destacamos que a maioria das postagens se referem a somente um perfil, então podemos deduzir que há um padrão de postagens desta página e não exatamente uma preferência do público. Isso pode ser decorrente de não haver uma prevalência de mapas sendo postados com essas hashtags (Quadro 1) ou os mapas não representarem um interesse dos seguidores. Robinson (2019, p. 307) também reflete sobre isso: "precisamos entender por que os usuários compartilham um mapa (...), bem como por que alguns usuários são motivados a criar seus próprios mapas".

Ademais, observam-se variados cenários quanto à média de curtidas e comentários entre mapas e "não mapas ${ }^{11 " . ~ N o ~ p r i m e i r o, ~ e v i d e n c i a m o s ~ q u e ~ e m ~ a l g u n s ~}$ casos as publicações com mapas são minoria e também apresentam uma média de curtidas e comentários inferiores a postagem sem mapas, e.g \#geografiageral e \#geografianews na semana 4; em um segundo cenário temos uma predominância de mapas nos mais relevantes, porém as postagens sem mapas acumulam mais curtidas e comentários, e.g. \#geografiadobrasil e \#geografiageral na semana 3 e \#geopocket na semana 1; um terceiro cenário onde os mapas são minoria mas somam mais curtidas e comentários, e.g \#geografiasemdivisas na semana 1; e um quarto cenário onde os mapas são a maioria e também possuem maior média de curtidas e comentários, o que ocorre somente na \#geografiadobrasil na semana 1 e \#mapas e \#cartografia na semana 3.

Também evidenciamos que algumas hashtags não apresentaram mapas em nenhuma das semanas, como por exemplo a \#geocuriosidade, ou somente um mapa, e.g. \#geografiafisica em todas as semanas, e a \#geo que oscila entre um e nenhum mapa. Ressalta-se que a \#geo é a hashtag com maior número de postagens (Quadro 1). Outro fato que chama a atenção é a não predominância de mapas em hashtags voltadas para o tema como \#cartografias e \#mapas, sendo que somente na semana 3 houve tal prevalência em \#mapas. Isso evidencia uma fragilidade do uso de hashtags na busca de conteúdos, visto que alguns usuários podem fazer uso de determinada hashtag, sem necessariamente se remeter ao assunto postado.

\footnotetext{
${ }^{11} \mathrm{O}$ termo "Não mapa" se refere as postagens sem mapas.
} 
Quadro 2 Planilha cromática da análise das hashtags por semana. (Legenda: não há mapas; 1-3 mapas; 4-6 mapas; e 7-8 mapas)

\begin{tabular}{|c|c|c|c|c|}
\hline $\begin{array}{l}\text { Hashtag } \\
\text { usada }^{12}\end{array}$ & Semana 1 & Semana 2 & Semana 3 & Semana 4 \\
\hline geografianews & $\begin{array}{l}\text { Não há mapas; } \\
9 \text { não mapas: Média } \\
\text { de } 2200 \text { curtidas e } 32 \\
\text { comentários. }\end{array}$ & $\begin{array}{l}\text { Não há mapas; } \\
9 \text { não mapas: } \\
\text { Média de } 1900 \\
\text { curtidas e } 27,2 \\
\text { comentários. }\end{array}$ & $\begin{array}{l}3 \text { mapas: } 2550 \\
\text { curtidas e } 39 \\
\text { comentários; } \\
6 \text { não mapas: } 2000 \\
\text { curtidas e } 32 \\
\text { comentários. }\end{array}$ & $\begin{array}{l}1 \text { mapa: } 115 \\
\text { curtidas e } 6 \\
\text { comentários; } \\
8 \text { não mapas: } \\
1894 \text { curtidas e } 30 \\
\text { comentários. }\end{array}$ \\
\hline geocuriosidades & $\begin{array}{l}\text { Não há mapas; } \\
9 \text { não mapas: média } \\
\text { de } 407 \text { curtidas e } 35 \\
\text { comentários. }\end{array}$ & $\begin{array}{l}\text { Não há mapas; } \\
9 \text { não mapas: } \\
\text { média de } 111 \\
\text { curtidas e } 9 \\
\text { comentários. }\end{array}$ & $\begin{array}{l}\text { Não há mapas; } \\
9 \text { não mapas: média } \\
\text { de } 389 \text { curtidas e } 34 \\
\text { comentários. }\end{array}$ & $\begin{array}{l}\text { Não há mapas; } \\
9 \text { não mapas: } \\
\text { média de } 392 \\
\text { curtidas e } 34 \\
\text { comentários. }\end{array}$ \\
\hline geografiageral & $\begin{array}{l}3 \text { mapas: } 11283 \\
\text { curtidas e } 106 \\
\text { comentários; } \\
6 \text { não mapas: } 6478 \\
\text { curtidas e } 82 \\
\text { comentários. }\end{array}$ & $\begin{array}{l}2 \text { mapas: } 5560 \\
\text { curtidas e } 37 \\
\text { comentários; } \\
7 \text { não mapas: } 8790 \\
\text { curtidas e } 139 \\
\text { comentários. }\end{array}$ & $\begin{array}{l}5 \text { mapas: } 4922 \\
\text { curtidas e } 48 \\
\text { comentários; } \\
\mathbf{4} \text { não mapas: } \\
11357 \text { curtidas e } 215 \\
\text { comentários. }\end{array}$ & $\begin{array}{l}2 \text { mapas: } 3881 \\
\text { curtidas e } 30 \\
\text { comentários; } \\
7 \text { não mapas: } \\
11587 \text { curtidas e } \\
98 \text { comentários. }\end{array}$ \\
\hline $\begin{array}{l}\text { geografiasemlim } \\
\text { ites }\end{array}$ & $\begin{array}{l}1 \text { mapa: } 4716 \text { curtidas } \\
\text { e } 52 \text { comentários; } \\
8 \text { não mapas: } 3954 \\
\text { curtidas e } 47 \\
\text { comentários. }\end{array}$ & $\begin{array}{l}\text { Não há mapas; } \\
9 \text { não mapas: } \\
\text { média de } 5212 \\
\text { curtidas e } 57 \\
\text { comentários. }\end{array}$ & $\begin{array}{l}2 \text { mapas: } 3881 \\
\text { curtidas e } 110 \\
\text { comentários; } \\
7 \text { não mapas: } 5699 \\
\text { curtidas e } 64 \\
\text { comentários. }\end{array}$ & $\begin{array}{l}3 \text { mapas: } 3026 \\
\text { curtidas e } 82 \\
\text { comentários; } \\
6 \text { não mapas: } \\
7260 \text { curtidas e } 78 \\
\text { comentários. }\end{array}$ \\
\hline geografia & $\begin{array}{l}3 \text { mapas: média de } \\
5502 \text { curtidas e } 236 \\
\text { comentários; } \\
6 \text { não mapas: média } \\
\text { de } 3259 \text { curtidas e } 85 \\
\text { comentários }\end{array}$ & $\begin{array}{l}1 \text { mapa: } 4667 \\
\text { curtidas e } 126 \\
\text { comentários; } \\
8 \text { não mapas: } 3224 \\
\text { curtidas e } 34 \\
\text { comentários }\end{array}$ & $\begin{array}{l}4 \text { mapas: média de } \\
3243 \text { curtidas e } 50 \\
\text { comentários; } \\
5 \text { não } \\
\text { mapas: média de } \\
5417 \text { curtidas e } 122 \\
\text { comentários }\end{array}$ & $\begin{array}{l}1 \text { mapa: } 4044 \\
\text { curtidas e } 277 \\
\text { comentários; } \\
\mathbf{8} \text { não mapas: } \\
10548 \text { curtidas e } \\
108 \text { comentários }\end{array}$ \\
\hline $\begin{array}{l}\text { geografiasemfro } \\
\text { nteiras }\end{array}$ & $\begin{array}{l}\text { Não há mapas; } \\
9 \text { não mapas: } 1450 \\
\text { curtidas de média e } \\
25,1 \text { comentários. }\end{array}$ & $\begin{array}{l}\text { Não há mapas; } \\
9 \text { não mapas: } 1503 \\
\text { curtidas de média e } \\
27 \text { comentários. }\end{array}$ & $\begin{array}{l}3 \text { mapas: } 2550 \\
\text { curtidas e } 39 \\
\text { comentários; } \\
6 \text { não mapas: } 2000 \\
\text { curtidas e } 32 \\
\text { comentários. }\end{array}$ & $\begin{array}{l}3 \text { mapas: } 2550 \\
\text { curtidas e } 39 \\
\text { comentários; } \\
6 \text { não mapas: } \\
2495 \text { curtidas e } 36 \\
\text { comentários. }\end{array}$ \\
\hline geo & $\begin{array}{l}\text { Não há mapas; } \\
9 \text { não mapas: média } \\
\text { de curtidas } 5500 \text { e } 58 \\
\text { comentários. }\end{array}$ & $\begin{array}{l}1 \text { mapa: } 6387 \text { e } \\
\text { sem comentários; } \\
8 \text { não mapas: } 5700 \\
\text { e } 57 \text { comentários. }\end{array}$ & $\begin{array}{l}\text { Não há mapas; } \\
9 \text { não mapas: } \\
\text { Média de curtidas } \\
5499 \text { e } 42 \text { de } \\
\text { comentários. }\end{array}$ & $\begin{array}{l}1 \text { mapa: } 3600 \\
\text { curtidas e } 115 \\
\text { comentários; } \\
8 \text { não mapas: } \\
\text { média de curtidas } \\
5499 \text { e } 70 \text { de } \\
\text { comentários. }\end{array}$ \\
\hline
\end{tabular}

\footnotetext{
${ }^{12} \mathrm{O}$ número de comentários e curtidas para postagens sem mapas no formato de vídeos (Reels) não foram contabilizados.
} 


\begin{tabular}{|c|c|c|c|c|}
\hline geografiaenem & $\begin{array}{l}\text { Não há mapas; } \\
9 \text { não mapas: média } \\
\text { de } 167 \text { curtidas e } 16 \\
\text { comentários }\end{array}$ & 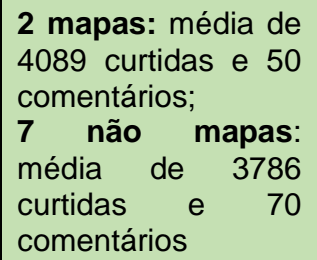 & $\begin{array}{l}2 \text { mapas: A média de } \\
806 \text { curtidas e } 33,5 \\
\text { comentários; } \\
7 \\
\text { mapas: média de } \\
3283 \text { curtidas e } 62,5 \\
\text { comentários }\end{array}$ & $\begin{array}{l}2 \text { mapas: média de } \\
124 \text { curtidas e } 5,5 \\
\text { comentários; } \\
7 \text { não mapas: } \\
\text { possuem média de } \\
2994 \text { curtidas e } \\
47,5 \text { comentários }\end{array}$ \\
\hline geografiafisica & $\begin{array}{l}1 \text { mapa: } 116 \text { curtidas } \\
\text { e } 15 \text { comentários; } \\
8 \text { não mapas: média } \\
\text { de } 1582 \text { curtidas e } 33 \\
\text { comentários }\end{array}$ & $\begin{array}{l}1 \text { mapa: } 517 \\
\text { curtidas e } 9 \\
\text { comentários; } \\
8 \text { não mapas: } \\
\text { média de } 2455 \\
\text { curtidas e } 54 \\
\text { comentários }\end{array}$ & $\begin{array}{l}1 \text { mapa: } 517 \text { curtidas } \\
\text { e } 9 \text { comentários; } \\
8 \text { não mapas: média } \\
\text { de } 3741 \text { curtidas } \\
51,7 \text { comentários }\end{array}$ & $\begin{array}{lr}1 \text { mapa: } & 1146 \\
\text { curtidas e } & 10 \\
\text { comentários; } \\
\mathbf{8} \text { não mapas: } \\
\text { média de } 3202 \\
\text { curtidas e } \\
\text { comentários }\end{array}$ \\
\hline geografiadobrasi & $\begin{array}{l}6 \text { mapas: média } \\
\text { de } 742 \text { curtidas e } 45 \\
\text { comentários; } \\
3 \text { não mapas: média } \\
\text { de } 544 \text { curtidas e } 22 \\
\text { comentários. }\end{array}$ & $\begin{array}{l}4 \text { são mapas: } \\
\text { média de } 2774 \\
\text { curtidas e } 104 \\
\text { comentários; } \\
5 \text { não mapas: } \\
\text { média de } 647 \\
\text { curtidas e } 48 \\
\text { comentários. }\end{array}$ & $\begin{array}{l}6 \text { mapas: média de } \\
156 \text { curtidas e } 39 \\
\text { comentários; } \\
3 \text { não mapas: média } \\
\text { de } 375 \text { curtidas e } 37 \\
\text { comentários. }\end{array}$ & $\begin{array}{l}5 \text { mapas: média } \\
\text { de } 721 \text { curtidas e } \\
46 \text { comentários; } \\
4 \text { não mapas: } \\
\text { média de } 329 \\
\text { curtidas e } 28 \\
\text { comentários. }\end{array}$ \\
\hline geopocket & $\begin{array}{l}6 \text { mapas: média de } \\
2562 \text { curtidas e } 369 \\
\text { comentários; } \\
3 \text { não mapas: com } \\
\text { uma média de } 57.517 \\
\text { curtidas e r } 125 \\
\text { comentários. }\end{array}$ & $\begin{array}{l}8 \text { mapas: sendo } 2 \\
\text { com gif. Os } 6 \\
\text { mapas possuem } \\
\text { uma média de } 3058 \\
\text { curtidas e } 33 \\
\text { comentários. Os } \\
\text { posts com gif } \\
\text { obtiveram } 88.840 \\
\text { mil visualizações e } \\
60 \text { mil } \\
\text { visualizações; } \\
2 \text { não mapas: são } \\
\text { gifs com } 144 \text { mil } \\
\text { visualizações e } \\
20.352 \text { mil } \\
\text { visualizações, } \\
\text { respectivamente. }\end{array}$ & $\begin{array}{l}6 \text { são mapas, sendo } \\
2 \text { com gif. Os } 4 \\
\text { mapas possuem } \\
\text { uma média de } 3214 \\
\text { curtidas e } 65 \\
\text { comentários. Os gifs } \\
\text { com média de } \\
80.000 \\
\text { visualizações; } \\
3 \text { não mapas: média } \\
\text { de } 57.852 \\
\text { visualizações e } 126 \\
\text { comentários. }\end{array}$ & $\begin{array}{l}5 \text { mapas. } 4 \text { sem } \\
\text { gif e } 1 \text { com gif: } \\
\text { Média dos } 4 \\
\text { mapas: } 1.622 \\
\text { curtidas e } 51 \\
\text { comentários. O gif } \\
\text { com mapa possuiu } \\
102.539 \\
\text { visualizações e } 36 \\
\text { comentários; } \\
4 \text { não mapas, } \\
\text { sendo } 3 \text { dessas, } \\
\text { com gif. A } \\
\text { postagem sem gif } \\
\text { possui } 2679 \\
\text { curtidas e } 42 \\
\text { comentários. }\end{array}$ \\
\hline $\begin{array}{l}\text { geografiasemdiv } \\
\text { isas }\end{array}$ & $\begin{array}{l}3 \text { mapas: média de } \\
3284 \text { curtidas e } 62 \\
\text { comentários; } \\
6 \text { não mapas, média } \\
\text { de } 1719 \text { curtidas e } 19 \\
\text { curtidas. }\end{array}$ & $\begin{array}{l}3 \text { mapas: média de } \\
1188 \text { curtidas e } 27 \\
\text { comentários; } \\
6 \text { não mapas, } \\
\text { média de } 1470 \\
\text { curtidas e } 27 \\
\text { comentários. }\end{array}$ & $\begin{array}{l}1 \text { mapa: } 3042 \\
\text { curtidas e } 89 \\
\text { comentários; } \\
8 \text { não mapas: média } \\
\text { de } 2.901 \text { curtidas e } \\
74 \text { comentários. }\end{array}$ & $\begin{array}{l}1 \text { mapa: } 327 \\
\text { curtidas e } 54 \\
\text { comentários; } \\
8 \text { não mapas: } \\
\text { média de } 2.993 \\
\text { curtidas e } 106 \\
\text { comentários }\end{array}$ \\
\hline geografía & $\begin{array}{l}6 \text { mapas: média de } \\
3.609,8 \text { curtidas e } \\
120,1 \text { comentários; } \\
3 \text { não mapas: média } \\
\text { de } 3.005 \text { curtidas e } \\
39,6 \text { comentários. }\end{array}$ & $\begin{array}{l}4 \text { mapas: média de } \\
5.281 \text { curtidas e } 218 \\
\text { comentários; } \\
5 \text { não mapas: } \\
\text { média de } 10.067 \\
\text { curtidas e } 287,6 \\
\text { comentários. }\end{array}$ & $\begin{array}{l}4 \text { mapas: média de } \\
4.252,25 \text { curtidas e } \\
129 \text { comentários; } \\
4 \text { não mapas e um } \\
\text { Reels: média de } \\
8.515,5 \text { curtidas e } \\
304,75 \text { comentários. }\end{array}$ & $\begin{array}{l}3 \text { mapas: média } \\
\text { de } 5.781 \text { curtidas e } \\
238 \text { comentários; } \\
4 \text { não mapas e } 2 \\
\text { Reels: média de } \\
7.772,7 \text { curtidas e } \\
97,25 \text { comentários. }\end{array}$ \\
\hline mapas & $\begin{array}{l}3 \text { mapas: média de } \\
2.242 \text { curtidas e } 61 \\
\text { comentários; } \\
6 \text { não mapas: média } \\
\text { de } 9.385 \text { curtidas e } 95 \\
\text { comentários. }\end{array}$ & $\begin{array}{l}3 \text { mapas e um } \\
\text { vídeo: média de } \\
5.106 \text { curtidas e } 187 \\
\text { comentários. } \\
\text { Vídeo: } 60.168 \\
\text { visualizações e } 44 \\
\text { comentários. }\end{array}$ & $\begin{array}{l}7 \text { mapas e } 1 \text { vídeo: } \\
\text { média de } 4.718 \\
\text { curtidas e } 108 \\
\text { comentários; } \\
\text { Vídeo: } 73.362 \\
\text { visualizações e } 44 \\
\text { comentários. }\end{array}$ & $\begin{array}{l}4 \text { mapas: média } \\
\text { de } 4.364 \text { curtidas e } \\
195 \text { comentários; } \\
5 \text { não mapas: } \\
\text { média de } 1.276 \\
\text { curtidas e } 32 \\
\text { comentários. }\end{array}$ \\
\hline
\end{tabular}




\begin{tabular}{|l|l|l|l|l|}
\hline & & $\begin{array}{l}\text { 5 não mapas: } \\
9.390 \text { curtidas e 81 } \\
\text { comentários. }\end{array}$ & $\begin{array}{l}\text { 1 não mapa: 3.158 } \\
\text { curtidas e 43 } \\
\text { comentários. }\end{array}$ & \\
\hline cartografias & $\begin{array}{l}\text { 1 mapa: 285 curtidas } \\
\text { e 2 comentários; } \\
7 \text { não mapas e 1 } \\
\text { vídeo: média de 190 } \\
\text { curtidas e 15 } \\
\text { comentários }\end{array}$ & $\begin{array}{l}\text { 1 mapa: 285 } \\
\text { curtidas e 2 } \\
\text { comentários; } \\
\text { 7 não mapas e 1 } \\
\text { vídeo: média de } \\
169 \text { curtidas e 11 } \\
\text { comentários }\end{array}$ & $\begin{array}{l}\text { Não há mapas; } \\
\mathbf{8} \text { não mapas e 1 } \\
\text { vídeo: média de 242 } \\
\text { curtidas e 10 } \\
\text { comentários. }\end{array}$ & $\begin{array}{l}\text { 1 mapa: } 285 \\
\text { curtidas e 2 } \\
\text { comentários; } \\
\mathbf{7} \text { não mapas e 1 } \\
\text { vídeo: média de } \\
166 \text { curtidas e 11 } \\
\text { comentários }\end{array}$ \\
\hline
\end{tabular}

Fonte: Elaborado pelos autores, 2021

Quanto a viralidade temporal dos mapas, tempo que permanecem na seção de destaque das hashtags, observamos diferenças de acordo com o número de postagens das hashtags. Nas hashtags com maior número de postagens, como na \#geografia (592.953 postagens) e \#geo (1.072.913 postagens) os mapas e demais postagens nunca permaneceram mais de uma semana em destaque. Em contrapartida, em hashtags com menos de 2.000 publicações como é o caso da \#geografiasemdivisas, os mapas permaneceram por mais tempo, como um mapa sobre a muralha verde na África que permaneceu por todas as semanas. Na \#geopocket (1572 postagens) os mapas tendiam a permanecer por 2, 3 e até 4 semanas, como é o caso do "Mapa gentílico dos estados brasileiros".

Em hashtags entre 2000 e 10.000 postagens também ocorrem padrões similares, com os mapas ocupando os conteúdos de destaque entre duas e três semanas. Na \#geografianews (4979 postagens) o mapa que permaneceu em destaque por duas semanas foi sobre os "Blocos Econômicos da América Latina"; na \#geografiafisica (6023 postagens) foi o mapa sobre "as regiões áridas (desérticas) e semiáridas pelo mundo"; na \#geografiaenem (8057 postagens) um deles com a temática de "porcentagem de população dentro de cada região brasileira" e outro mapa "dos municípios em isolamento rodoviário com o restante do Brasil"; na \#geografiasemfronteira (4089 postagens), foram os mapas sobre "Blocos econômicos da América do Sul", "Taxa de homicídio no Brasil" e "Língua inglesa como língua oficial no mundo". E o caso da \#geografiadobrasil (7295 postagens) na qual houve poucas alterações durante as semanas analisadas, o que ocorreu é de um mapa que estava em primeira posição, trocar com outro de posição inferior, com mapas ocupando a posição de destaque todas as quatro semanas.

Outra observação que pode ser feita, é que quando uma hashtag chega a um ponto de cristalização na qual uma única página com muitos seguidores domina sua seção de destaque, há uma tendência de que outras páginas não a utilizem por um período, pois não teriam chance de engajamento suficiente para estar entre os destaques. Páginas que buscam engajamento, normalmente, fazem esse tipo de análise. Um exemplo ocorre na \#mapas (114.619 publicações) onde a postagem sobre as exportações dos estados brasileiros e sobre as rodovias do Brasil permaneceram em posição de destaque durante 4 semanas e na \#geografia onde os mapas de destaque sempre pertenciam ao mesmo perfil.

Destacamos que também há uma questão de assunto do mapa que pode implicar na sua viralidade temporal. Robinson (2019) corrobora que o "contexto da mensagem" em mapas virais diz respeito ao cenário em que foram criados. Nas semanas 2, 3 e 4 observamos que mapas relacionados ao dia da água (22 de março) foram frequentes na seção de destaque da \#geografia, \#geopocket, \#geografiafisica \#geografiageral como "Aquíferos na América do Sul", "Segurança Hídrica no Brasil", 
"Estimativa de escassez global de água em 2025" e "Bacias hidrográficas do mundo", "Como os rios fluem na América do Sul" e "Rios da América do Sul".

Entre os assuntos que dominaram essas seções de destaque das hashtags (Figura 04) temos em primeiro os gentílicos de capitais brasileiras (4 vezes), gentílico dos estados brasileiros (4 vezes), gentílicos de capitais nordestinas (1 vezes). Estes mapas costumam ter bastante interação nos comentários, visto que, os usuários acabam indicando sua origem. Os temas de população ou densidade populacional se destacam (6 vezes), blocos econômicos, mapas antigos, tamanho do Brasil, rios da América do Sul se destacam cada qual com 4 mapas. Também destacamos que o assunto "rodovias" aparece como tema de 11 mapas, com propósitos diferentes: em \#geopocket e \#mapas, o mapa de "Rodovias federais transversais, radiais, longitudinais, diagonais e de ligação do Brasil" aparece 6 vezes. O mapa com "países que falam a língua inglesa" se sobressaiu com 5 destaques em \#geografianews, \#geografiasemfronteiras e \#mapas. O "Mapa mundi com países que falam português" também teve relevância com 4 destaques em \#geografía.

Figura 4.Títulos/assuntos ${ }^{13}$ dos mapas que estavam em destaque nas 15 hashtags analisadas $^{14}$

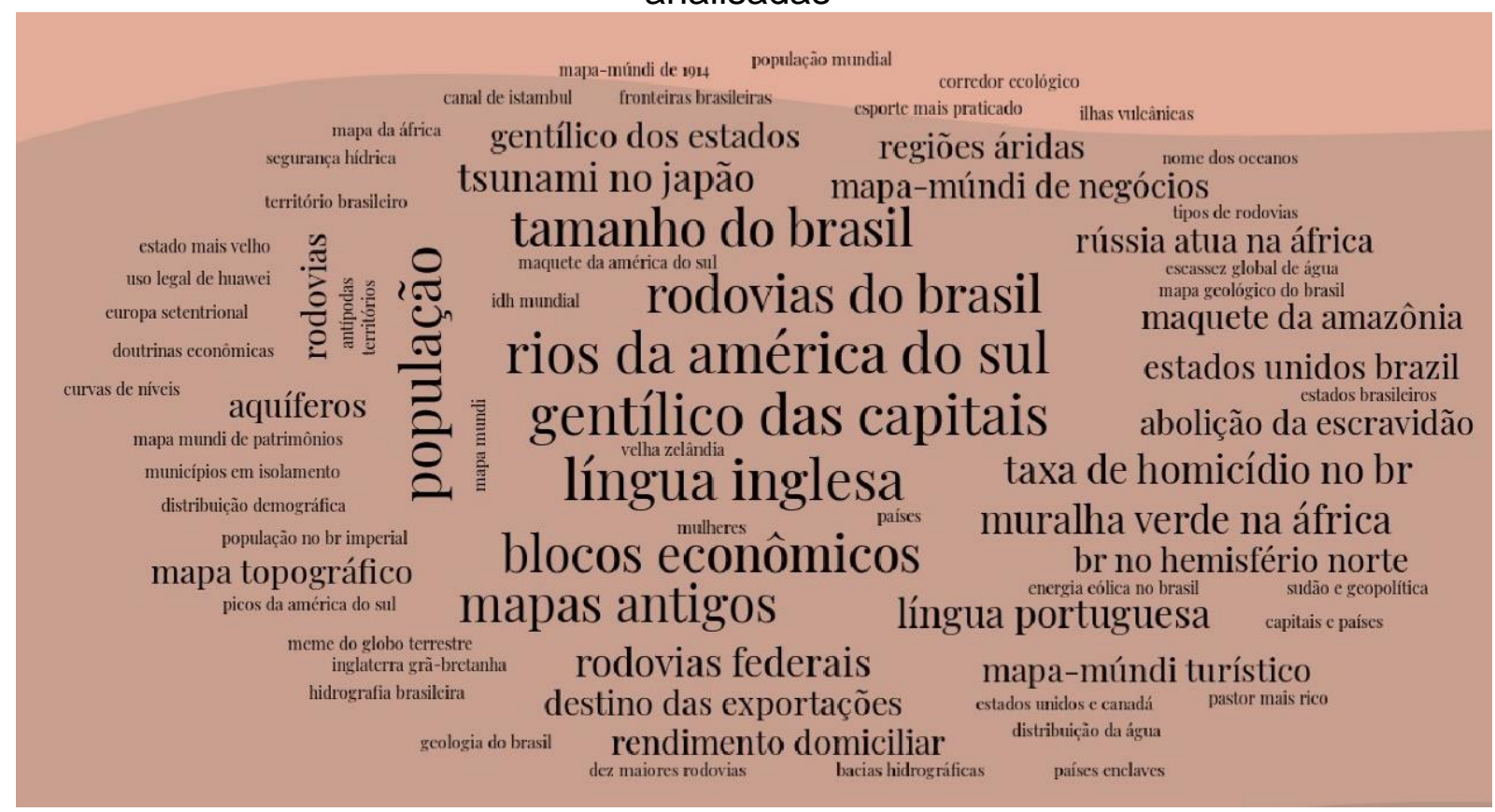

Fonte: Elaborado pelos autores, 2021

INTERPRETAÇÃO DOS MAPAS ATRAVÉS DOS COMENTÁRIOS DOS USUÁRIOS: POR QUE OS OCEANOS NÃO ESTÃO NA COR AZUL?

Observando os comentários dos seguidores nos mapas em destaque das hashtags, algumas importantes discussões podem ser trazidas. Salientamos que os comentários são uma maneira de responder a uma preocupação exposta por Robinson (2019, p. 296) em relação à Cartografia Viral "[...] sabemos relativamente pouco sobre a leitura do mapa e habilidades de interpretação de usuários de mídia social". Quanto aos assuntos com potencial viral, destacamos que o navio Ever Given,

\footnotetext{
${ }^{13}$ Quando os títulos dos mapas apresentavam muitas palavras, foram resumidos ao seu assunto.

${ }^{14}$ Os títulos dos mapas precisaram ser resumidos em função da limitação de caracteres do site Mentimeter
} 
que encalhou no canal de Suez em 23 de março e foi removido em 30 de março de 2021, foi um conteúdo com muito engajamento nas hashtags analisadas. Uma postagem sobre o navio na \#geografia chegou a 29.600 curtidas e na \#geografiageral, a postagem sobre o navio obteve 32.306 curtidas, sendo a publicação com maior número de likes comparando com todas que foram analisadas com essa hashtag. $\mathrm{Na}$ \#geopocket uma postagem sobre o navio também ocupou o primeiro lugar na última semana de análise. Enfatizamos que os mapas e imagens de satélite sobre o navio não estavam na seção de destaque, somente memes.

Foram encontrados muitos comentários que fazem uma interpretação do mapa, trazendo dúvidas sobre os dados e/ou elementos cartográficos. Na postagem sobre a "diferença entre Inglaterra, Grã-bretanha e Reino Unido", houve questionamentos nos comentários sobre se é possível usar a cor azul no mapa sem ser para água, em \#geografiasemdivisas. Na \#geografia têm-se um mapa sobre a "Estimativa de escassez global de água em 2025", no qual um seguidor comenta "Porque os oceanos não estão da cor azul???? ${ }^{15 ", ~ s e ~ r e f e r i n d o ~ a ~ u m a ~ c o n v e n c ̧ a ̃ o ~ c a r t o g r a ́ f i c a . ~ C o n t u d o, ~ o ~}$ azul faz parte da representação temática do assunto. Nas \#geografianews e \#geografiasemfronteiras também havia comentários de seguidores pedindo o que determinada cor significava, já que a cor não estava na legenda. Na \#geografia o mapa sobre as "fronteiras internacionais do Brasil" não possuía legenda gerando diversos comentários sobre dúvidas em relação às cores utilizadas.

Ressaltamos que comumente as pessoas trazem em seu imaginário a cor azul convencionada para água, talvez, devido às práticas escolares que colocam a cor como de uso exclusivamente para a água. Todavia, em Cartografia Temática, tem-se claro que seu uso não é exclusivo. Há temas variados que podem utilizar o azul ou degradês que utilizam o azul, por exemplo, ao pensarmos na representação da temperatura é correto utilizar na sequência de tons de azul para áreas mais frias, sem estarmos falando em água. Por outro lado, ao visualizarmos a água na natureza ela não é necessariamente azul, ou seja, há uma convenção para representá-la em azul, contudo, esse não é o único elemento que pode ou deve utilizar tal cor. Ademais, tal convenção é mais forte em termos de Cartografia Geral do que em Cartografia Temática.

Outro mapa da \#geografia teve como temática a "origem e distribuição das religiões afro-brasileiras", apresentou o seguinte comentário "Poderia ter dado um pouquinho mais de contraste, para os daltônicos. Não tô conseguindo diferenciar a cor dos últimos três grupos", o que nos faz questionar o quanto os mapas podem ou não serem acessíveis nas mídias sociais. Robinson (2019, p. 296) já destacou sobre as convenções cartográficas que "símbolos confusos, esquemas de cores que não correspondem aos dados de maneira adequada e o uso de cores problemáticas para leitores daltônicos podem dificultar a capacidade de um mapa se tornar viral". Sobretudo, o uso de cores sem estarem representadas na legenda, geraram muitas dúvidas para a leitura dos mapas. Deixamos a nossa inquietação: "como os mapas virais estão sendo interpretados pelos usuários se não possuem os elementos cartográficos fundamentais?".

$\mathrm{Na}$ \#geografia, um mapa intitulado "A população do Brasil Imperial", encontramos um comentário sobre generalização cartográfica em um mapa sem escala "a ilha do Marajó era ligada ao continente?'. Apesar de se tratar de uma questão de interpretação do usuário das redes sociais, a ausência da escala é determinante para causar dúvidas na leitura do mapa. Outro comentário ainda nesse

\footnotetext{
${ }^{15}$ Os comentários foram copiados da mídia social Instagram sem alterações.
} 
mapa questiona uma informação que não está novamente presente na legenda "oq é esse neutro abaixo do rj?'. Apesar de ter o elemento obrigatório de legenda, não está completa.

$\mathrm{Na}$ maquete da América do Sul, na \#geografia destaca-se um comentário "Perfeito não acho que esteja nao, a cordilheira está muito desproporcional!" onde o seguidor não compreende o exagero vertical utilizado, e de fato, este não foi mencionado. Nieścioruk (2020) destacou que os mapas podem ser difíceis de interpretar nas mídias sociais. Ressaltamos que houveram ausências de elementos cartográficos obrigatórios ou foram utilizados de forma incompleta ou equivocada, e os comentários demonstram que há vários problemas na interpretação desses mapas.

Ainda mais preocupante, foram encontrados 3 mapas com erros e os comentários de alguns usuários demonstram a preocupação com o repasse de informações equivocadas. Na \#geografia um mapa sobre as "fronteiras internacionais do Brasil" possui vários comentários questionando o número de habitantes da zona fronteiriça, que de fato está errada, pois aponta um total de 730 mil habitantes sendo que somente Foz do Iguaçu (PR) e Porto Velho (RO) já acumulariam esse montante. Novamente na \#geografia um mapa sobre as rodovias do Brasil apresentou um erro. Um dos comentários reflete "Mas ta errado isso ai. Cade a br163 que vai do mato grosso até o para, por exemplo?".

$\mathrm{Na}$ \#geografianem encontramos um mapa de países enclaves, com comentários apontando um erro "Oh.. Eu acho que os países dentro da Itália estão invertidos" e apontando outros países que não foram citados. Destaca-se que o perfil responsável pela publicação admitiu o erro, porém não excluiu o conteúdo. Tratandose de uma hashtag específica para os estudantes do ENEM, percebe-se a disseminação de informações falsas, prejudicando os seguidores e induzindo a erros conceituais e de interpretação dos conteúdos veiculados.

Robinson (2019, p. 308) destacou que "mapas falsos já podem estar presentes em fontes de mídia social, sejam criados manualmente ou mesmo criados por processos automatizados". Nieścioruk (2020) também destacou que os mapas podem conter informações falsas. De fato, comprovamos que entre os mapas de destaque das hashtags avaliadas, 3 deles apresentaram erros. E o que é mais preocupante, diante da indicação do erro, o perfil responsável não ter feito a correção ou exclusão da informação. Infelizmente, a preocupação com o engajamento social da página se sobressai, em muitos casos, e não o compromisso com o uso de dados e bases cartográficas confiáveis.

\section{CONSIDERAÇÕES FINAIS}

Destaca-se que o uso das hashtags representaram um aumento no número de contas alcançadas, impressões e seguidores, além de possivelmente terem apresentado o nosso conteúdo a seguidores que não eram ligados à Geografia, principalmente nas postagens de cunho interdisciplinar. $O$ uso de um layout único também significou a busca por uma identidade dentro do ciberespaço, significando um grande aumento de seguidores logo em seguida a adoção deste padrão. Embora, não tenhamos conseguido emplacar postagens na seção de destaque da grande maioria das hashtags utilizadas.

Robinson (2019) apontou o quanto é difícil apontar o potencial de engajamento social e por quanto tempo um mapa permanecia como viral, e destacamos que através das hashtags e da seção de postagens de destaque do Instagram é possível se ter uma noção e algumas primeiras respostas ao questionamento exposto pelo autor 
precursor da Cartografia Viral. Além disso, a vantagem das hashtags é justamente facilitar a busca de conteúdos e concentrar postagens facilitando a análise, por nós pesquisadores, assim como para aqueles que consomem o material, os seguidores.

Reforçamos que os mapas possuem grande potencial de comunicação, dentro da lógica das redes sociais. Contudo, os mapas não foram a maioria dentro da seção de destaque das hashtags, nem em hashtags voltadas para tal como \#mapa e \#cartografia. Isso demonstra o quanto ainda precisamos entender sobre os conteúdos que mais viraliza e explorar o potencial dos mapas para a comunicação. Contudo, percebe-se que temas relacionados a curiosidades e assuntos muito debatidos no momento, que já trazem a viralidade em si, fomentaram a disseminação de mapas virais, como ocorreu com as postagens na semana pós ENEM.

Nota-se que mesmo que uma postagem possua as mesmas hashtags, a ocupação da seção de destaque não ocorre em todas. Em muitas hashtags, há uma constância na seção de destaque, o que não repercute diretamente em engajamento contínuo, mas sim, que as demais publicações não alcançam o potencial envolvimento das que estão cristalizadas no top 9 para superá-las. Isso ocorreu em hashtags com poucas postagens, pois não há perfis que as adotam e por isso seu feed não altera. Como exemplos disso pode-se citar a semana 3, nas hashtags \#geografianews e \#geografiasemfronteiras (ambas com menos de 5000 postagens) na qual os três mesmos mapas estavam em destaque (Blocos econômicos da América do Sul; taxa de homicídio no Brasil; língua inglesa como língua oficial no mundo) e na semana 4 somente o primeiro mapa citado permaneceu em destaque nas duas hashtags.

Por outro lado, em postagens de hashtags com grande número de publicações isso também foi verificado, porém ligado ao domínio de páginas com grande número de seguidores, impossibilitando que um perfil com menos seguidores consiga ocupar a seção de destaque. Como exemplo, temos o mapa de Rodovias do Brasil ou o vazio da Amazônia que na última semana estava em destaque em \#cartografias e \#mapas (mais de 70.000 seguidores).

Destacamos nossa preocupação em relação aos mapas virais fakes que já estão circulando pelo Instagram, ocupando hashtags com grande número de postagens e, consequentemente, de seguidores. A ausência, uso equivocado ou incompleto de convenções cartográficas como escalas e legendas também dificultam a leitura dos mapas. Enquanto alguns seguidores podem notar os erros, provavelmente muitos outros não percebem, classificando o erro como um dado verdadeiro.

Como trabalho futuro, sugere-se que a pesquisa seja realizada utilizando as mesmas hashtags, porém em diferentes plataformas de mídias sociais. Segundo Murzintcev e Cheng $(2017$, p. 3) "os usuários de plataformas de mídia social distintas, quando descrevem eventos semelhantes, tendem a usar hashtags semelhantes". Então, podemos verificar se os padrões do Instagram se repetem no Twitter, por exemplo, que é uma mídia social que possui a seção de "Trending Topics".

Por fim, Shannon e Walker (2020) destacam que a Cartografia Viral pode fornecer um caminho eficaz (e afetivo) para construir relações com públicos mais amplos, tal como os usuários de redes sociais. Destacamos a potencialidade das mídias sociais como um espaço de divulgação de pesquisas, de dicas sobre atividades pedagógicas, de educação geográfica, de interação e troca de ideias, como um espaço de conexão entre a academia e a sociedade. 


\section{REFERÊNCIAS BIBLIOGRÁFICAS}

BAUMAN, Z. Modernidade líquida. Rio de Janeiro: Jorge Zahar Ed., 2001.

CARMEAN, D.M.; MORRIS, M. E. Selfie examinations: Applying computer vision, hashtag scraping and sentiment analysis to finding and interpreting selfies. Tech. Rep. Intel Labs, p. 1-4, 2015.

FERRARA, E.; INTERDONATO, R.; TAGARELLI, A. Online popularity and topical interests through the lens of instagram Proceedings of the 25th ACM. Anais da $25^{\mathrm{a}}$ conferência ACM sobre hipertexto e mídia social, p. 24-34, ACM. 2014.

GIANNOULAKIS, T.; TSAPATSOULIS, N. Evaluating the descriptive power of Instagram hashtags. Journal of Innovation in Digital Ecosystems, v. 3, n. 2, p. 114129, 2016.

GOEL, S., A. ANDERSON, J. HOFMAN, D. J. WATTS. The Structural Virality of Online Diffusion. Management Science, v. 62, n. 1, p. 180-196, 2019.

LABADESSA, E. O uso das redes sociais na internet na sociedade brasileira. RMS Revista Metropolitana de Sustentabilidade, v. 2, n. 2, p. 82-94, 2012.

MUEHLENHAUS, I. Going viral: The look of online persuasive maps. Cartographica. The International Journal for Geographic Information and Geovisualization, v. 49, n 1, p. 18-34, 2014.

MURZINTCEV, N.; CHENG, C. Disaster Hashtags in Social Media. ISPRS International Journal Of Geo-Information. v. 6, n. 7, p. 1-17, 2017.

NIEŚCIORUK, K. Like it! Maps as a Subject and a Springboard for discussion in social media. Polish Cartographical Review, v 52, n. 2., p. 51-60, 2015.

OMENA, J. J.; RABELLO, E. T.; MINTZ, A. G. Digital Methods for Hashtag Engagement Research. Social Media + Society. n. 3, p. 1-18, 2020.

RAUSCHNABEL, P. A; SHELDON, P.; HERZFELDT, E. What motivates users to hashtag on social media? Psychologhy \& Marketing, n. 36, p. 473-488, 2019.

ROBINSON, A. C. Elements of Viral Cartography. Cartography and Geographic Information Science, v. 46, p. 293-310, 2019.

SHANNON, J.; WALKER, K. E. Ventures into Viral Cartography: Waffle House, Educational Attainment, and the Social Life of Maps. The Professional Geographer, v. 72, p. $66-77,2020$.

SINPENG, A. Hashtag activism: social media and the \#FreeYouth protests in Thailand. Critical Asian Studies, p.1-14, 2021. 
THOMAS, V. L.; VINUALES, G. Understanding the role of social influence in piquing curiosity and influencing attitudes and behaviors in a social network environment. Psychology and Marketing, p. $884-893,2017$.

VERMELHO, S. C.; VELHO, A.P M.; BONKOVOSKI, A.; PIROLA, A. Refletindo sobre as redes sociais digitais. Educação e Sociedade, v. 35, n. 126, p.179-196, 2014.

YE, Z., HASHIM, N. H.; BAGHIROV, F.; MURPHY, J. Gender Differences in Instagram Hashtag Use. Journal of Hospitality Marketing \& Management, v. 27, n. 4, p. 386404, 2017. 